\title{
Indonesian Political Economic Policy and Economic Rights: an Analysis Of Human Rights in the International Economic Law
}

\author{
Ridwan Arifin ${ }^{1}$ \\ ${ }^{1}$ Faculty of Law, Universitas Negeri Semarang, Semarang, Central Java, Indonesia
}

Received February 17 2018, Accepted April 22 2019, Published May 312019

DOI 10.15294/jg.v16i1.18178

\begin{abstract}
The national and international economic development raises new problems besides the positive side of finance. International economic recession that has global impacts including in Indonesia presents its own challenges. One of the challenges faced is a serious impact on the fulfillment of economic and social rights. Various economic austerity measures were taken to maintain the country's economic stability. One of the most controversial is the reduction of subsidies in the health, social security, trade and education sectors. The unemployment rate also increased as a direct impact of these economic policies. This paper analyzes the rights of human rights in Indonesian political economic policy both on a national and international scale. This paper compares and analyzes various cases of Indonesian economic policy with the basic principles of human rights, especially social, economic and cultural rights. Studies in this paper cover the areas of study of International Economic and Trade Law, Human Rights Law, and International Law. This paper highlighted that economic policies in the form of reducing subsidies and austerity measures undermine a wide range of human rights human rights frameworks.
\end{abstract}

Keyword: Political Economy Policy; Trade; Human Rights; International Economic Law

\section{INTRODUCTION}

Humans are legal subjects who have the highest dignity. Every human being has the most basic rights, namely the right to life. Recognition of the inherent dignity and equal and inseparable rights of all humans is the basis of freedom, justice and world peace. Some essential human rights are in the sectors of economy, social, and culture (ECOSOC). In the Indonesian state, these rights are regulated in the 1945 Constitution ${ }^{1}$. Whereas in the international regulation of the regulation of protection in the economic, financial and cultural sectors was born from a Declaration issued by the United Nations through the General Assembly called the Universal Declaration of Human Rights (UDHR) on December 10, 1948. ${ }^{2}$ In its implementation, this Declaration afford to two important instruments which regulates the provisions of human rights, namely the International Covenant on Civil and Political Rights (ICCPR) which is included as Karel Vasak's first category of human rights generation; and the International Covenant on Economic, Social and Cultural Rights (ICESCR) which is categorized as the second generation of human rights. ${ }^{3}$

1 The 1945 Constitution (UUD 1945) stipulated the economic, social, and cultural rights, especially in the UUD 1945 Amendment, Changes to the Constitution contain a special section that regulates the protection and guarantee of citizens' human rights (Chapter XA, Articles 28A to 28J of the 1945 Constitution). See Bisariyadi, "Menyibak Hak Konstitusional yang Tersembunyi", Jurnal Hukum Ius Quia Iustum, Vol. 24 Issue 4, October, 2017, pp. 515-518

2 UDHR is a milestone document in the history of human rights and it recognized as a common standard of achievements for all peoples and all nations. It sets out, for the first time, fundamental human rights to be universally protected. UDHR specifically mentioned about the ECOSOC Rights, in Article 22. See OHCHR, "Universal Declaration of Human Rights", United Nations Human Rights Office of the High Commissioner, 2008, retrieved from https://www. ohchr.org/en/udhr/pages/Language.aspx?LangID=inz, also United Nations, "Universal Declaration of Human Rights", retrieved from http://www.un.org/en/universal-declaration-human-rights/

3 When human rights are being discussed, they are often divided up into three categories called generations. A reflec-

${ }^{*}$ E-mail : ridwan.arifin@mail.unnes.ac.id

Address : K1 Building, 1st Floor, UNNES, Sekaran, Gunungpati, Semarang p-ISSN 2599-0314 e-ISSN 2599-0306 Central Java, Indonesia, 50229 
The relationship between human rights and the economy in the context of social, economic and cultural rights attracts much attention and debate among legal experts. This arises because individuals have the right to human rights, including human rights to the economy. Economic rights in the context of international law are considered to be one of the most fundamental things. Because, in many analyzes of legal experts, economic rights have a profound effect on human rights.

Jacquart stated that with increasing uncertainty and various changes in the political and economic fields in the $19^{\text {th }}$ and $20^{\text {th }}$ centuries, the portrait of political and economic relations between individuals and countries has changed. ${ }^{4}$ Therefore, he stressed the need to clarify human rights in new contexts and discourses. Leading international economics law scholar Ernst-Ulrich Petersmann stated that in the 20th century there was a "Human Rights Revolution" which changed portraits including international economic law. ${ }^{5}$ This is not only an important development but also requires in-depth studies of the implications of the development of this human revolution. Petersman emphasized that both International Human Rights Law and International Economic Law there are duties to protect calls for stronger protection of human rights in international economic regulation, and it is confirmed that human rights revolution has a broader sectors, in all human basic needs.

Another important change that is happening today is that there are enough basic constitutions in various countries in the world that increasingly recognize human rights to the economy. Inclusion of economic rights shows the increasing importance of human rights to the economy (including in relation to international economic law).

One important instrument in regulating the rights to the economy is stipulated in Article 55 of the United Nations Charter. This article among others requires the United Nations to advance respect including promoting compliance with human rights, including human rights to the economy. Article 55 of the Charter of the United Nations contains the aim of the United Nations to promote "higher standards of living, full employment and conditions of economic and social progress and development; solutions of international economic, social, health and related problems and international cultural and educational cooperation."

This right to economy demands the need for protection as appropriate. Human rights and the rights to this economy have a fairly close relationship, and there are many experts, for example Booysen, referring to human rights in relation to international economic law as international economic human rights. Meanwhile Seidl Hovenveldern called it human rights of economic value. ${ }^{6}$

The various relations between human rights and the economy have generated a lot of expert criticism and input on the implementation of government economic policies because they have resulted in significant impacts on non-fulfillment of basic human rights relating to economic rights. Some studies, such as Viljam Engström, ${ }^{7}$ Margot E. Salomon, ${ }^{8}$ Thomas Cottier, ${ }^{9}$ Frank J. Garcia, ${ }^{10}$ Fokky Fuad, ${ }^{11}$ David Kinley, ${ }^{12}$ Nisar Mohammad bin

tion of the three generations of human rights can be seen in the popular phrase of the French Revolution: liberté, egalité, fraternité. These generations of human rights were first formally established by Karel Vasak, a Czech jurist, in 1979. This division of the types of human rights helps improve conversations about rights, especially those involving legislation and the role that governments play in human rights. See Lindsey Reid, "The Generations of Human Rights", Online Article, Institute for Human Rights The University of Alabama at Birmingham, January 14, 2019, retrieved from https://cas.uab.edu/humanrights/2019/01/14/the-generations-of-human-rights/

4 Aprilia Gayatri, et.al., "Hak Asasi Manusia dan Hukum Ekonomi Internasional, Kovenan Hak-Hak Ekonomi, Sosial dan Budaya/ICESCR 1966”, Paper on International Economic Law, Bandung, Faculty of Law Universitas Padjadjaran, 2008, p. 3.; M. Jacquart, "Economic, Social and Cultural Rights", in M. Bedjaoui (ed.), International Law: Achievements and Prospects, The Netherlands, United Nations Educational, Scientific, and Cultural Organization, 1991, pp. 10831104.

5 Ernst-Ulrich Petersmann, "Human Rights and International Economic Law: Common Constitutional Challenges and Changing Structures", EUI Working Papers, SSRN Electronic Journal, No. LAW 2012/07, pp. 11-12 DOI: 10.2139/ ssrn.2069895

6 Aprilia Gayatri, et.al., Op.Cit., p.4, see also Manuel Couret Branco, "Economics Againts Human Rights (The Conflicting Languages of Economics and Human Rights)", Capitalism Nature Socialism, Vol. 20 No. 1, 2009, pp. 85-87.

7 See Viljam Engström, “The Political Economy of Austerity and Human Rights Law”, Institute for Human Rights Working Paper, No. 1/2016, Abo Academy University, pp. 1-16.

8 See Margot E. Salomon and Colin Arnott, "Better Development Decision-making: Applying International Human Rights Law to Neoclassical Economics", Nordic Journal of Human Rights, 2014, Vol. 32, No. 1, pp. 44-74.

9 See Thomas Cottier, "Challenges Ahead in International Economic Law”, Journal of International Economic Law, 2019, Vol. 12 No. 1, pp. 1-30.

10 See Frank J. Garcia, “ Globalization, Inequality \& International Economic Law”, Religions, 2017, Vol. 8 No. 78, pp. 1-12, DOI: $10.3390 /$ rel8050078

11 See Fokky Fuad, "Hukum, Demokrasi, dan Pembangunan Ekonomi”, Lex Jurnalica, 2007, Vol.5 No. 1, December, pp. $1-10$.

12 David Kinley, Civilising Globalisation: Human Rights and the Global Economy, Cambridge, Cambridge University Press, 2009, pp. 38-40. 
Ahmad, ${ }^{13}$ and Ridwan Arifin, Rasdi, and Riska Alkadri ${ }^{14}$ showed that there are imbalances between human rights in various economic policies. Economic policies in many cases lead to inequality, discrimination and even threats to the basic principles of human rights. Furthermore, for example economic policies in the form of austerity measures and cuts in subsidies create a lot of unemployment and neglect of basic human rights.

In further conditions in Indonesia, the imbalance of economic policy presents problems not only for unemployment but also various problems such as deduction of wages for workers, eviction for the benefit of economic industrial development, high health costs and unclear social security, high fertilizer prices for farmers, high prices fuel, and reduction in education services. ${ }^{15}$

One of the latest conditions related to economic policy that has an impact on Indonesia is, the USA Policy on reviewing 124 Indonesian products that are shipped to the USA. These items could also become subject to import tariffs and may provoke retaliatory moves from Indonesia's Trade Ministry, and this situation would be bad for Indonesia and USA. Further, said that if economic growth in the United States and China is undermined by the trade war, then it will have a direct impact on Indonesian exports and-more generally- an impact on the Indonesian economy as China and the USA are both among Indonesia's biggest export destinations. Meanwhile, raw materials and commodities that are supplied by Indonesia to China (to make those products that have now become subject to US import tariffs) are likely to become affected as demand for these raw materials/ commodities is expected to fall accordingly. ${ }^{16}$

In addition, policies to improve infrastructure to support economic development also drew a lot of criticism. The policies taken by the government, for example the construction of infrastructure such as airports, roads, or new industries, are considered not to see a human rights approach. In the National Medium-Term and Long-Term Development Plan (RPJM-RPJPN) for example, there are many alliances and imbalances in human rights. In fact, based on human rights instruments, the state is placed as a duty holder and places the community as the right holder. This conception reaffirms that the state does not have rights that only carry out responsibilities and obligations. ${ }^{17}$ Meanwhile, The Institute for Community Research and Advocacy (Lembaga Studi dan Advokasi Masyarakat, eLSAM) emphasized that the economic policy package announced by the government had been more accommodating to the business interests of capital owners. The policy was also issued without an adequate protection framework for the community. ${ }^{18}$

Furthermore, in some international and bilateral agreements in economic, business, and trade sectors also raise many problems in the protection of human rights. The results of Migrant Care Indonesia's research that various Memorandums of Understanding (MoU), Laws, Presidential Regulations (Perpres), Presidential Instruction (Inpres), Ministerial Regulations (Permen), Ministerial Decrees (Kepmen), Regional Regulations (Perda), and Regulations Village (Perdes) none of the policies are guided by human rights principles and are merely business and economic oriented. One of them is the policy regarding labor migration where the impact of government policy. There were no significant changes in the policy products regarding the governance of the placement of Indonesian migrant workers, both before and after the Ratification of the International Convention on the Rights of Protection of Migrant Workers and Their Families which was ratified by the Parliament on 12 April 2012 and enacted in national law through Law Number 6 of 2012. ${ }^{19}$

13 Nisar Mohammad bin Ahmad, "The Economic Globalisation and its Threat to Human Rights", International Journal of Business and Social Science, 2011, Vol. 2 No. 19, October, pp. 273-280.

14 See Ridwan Arifin, Rasdi, Riska Alkadri, “Tinjauan atas Permasalahan Penegakan Hukum dan Pemenuhan Hak dalam Konteks Universalisme dan Relativisme Hak Asasi Manusia di Indonesia”, Jurnal Ilmiah Hukum LEGALITY, 2018 , Vol. 26 No.1, pp. 17-39, DOI: https://doi.org/10.22219/jihl.v26i1.6612.g5770

15 YLBHI, "Hak Ekonomi, Sosial dan Budaya di Negeri yang Kaya: Potret Pelanggaran Hak-hak Ekosob di Indonesia (Januari 2002 - Februari 2003)", Project Report YLBHI, No. 3, March, pp. 1-15. In other conditions and cases, all of these rights cannot be fulfilled by the government, especially rights relating to the poor and guarantees of legal assistance. More detail, please also see Angga \& Ridwan Arifin, "Penerapan Bantuan Hukum Bagi Masyarakat Kurang Mampu", DIVERSI Jurnal Hukum, 2018, Vol. 4 No. 2, pp. 218-236, DOI: https://doi.org/10.32503/diversi.v4i2.374

16 Anonym, "Economy of Indonesia is Facing Several Big Challenges", Online Article, 6 July 2018, retrieved from https:// www.indonesia-investments.com/news/news-columns/economy-of-indonesia-is-facing-several-big-challenges/ item 8882 ?

17 Agus Suntoro, "Perlunya Pendekatan HAM dalam Kebijakan Pembangunan Infrastruktur", Online Article, 15 January 2018, https://nasional.kompas.com/read/2018/01/15/21090441/perlunya-pendekatan-ham-dalam-kebijakan-pembangunan-infrastruktur

18 Lili Sunardi, "Paket Kebijakan Ekonomi Berpotensi Picu Pelanggaran HAM", Online News, 11 December 2015, retrieved from https://finansial.bisnis.com/read/20151211/9/500630/paket-kebijakan-ekonomi-berpotensi-picupelanggaran-ham

19 Restry Armenia, “Kebijakan Migrasi Pekerja Dinilai Picu Pelanggaran HAM Buruh”, Online News, 8 March 2016, retrieved from https:/www.cnnindonesia.com/nasional/20160307142904-26-115831/kebijakan-migrasi-pekerja-dinilai-picu-pelanggaran-ham-buruh. For more comprehensive condition and comparison, please also read Kania Dewi Andhika Putri \& Ridwan Arifin, "Tinjauan Teoritis Keadilan dan Kepastian dalam Hukum di Indonesia (The Theoretical Review of Justice and Legal Certainty in Indonesia)", MIMBAR YUSTISIA Jurnal Hukum dan Hak Asasi Manusia, 
The problems in economic policies generally come up from the principle of economic liberalism and capitalism, where in many cases this principle was not applicable for human rights protection. The principle of economic freedom in which includes free trade as well as business roles, both large business groups and small businesses, is often considered to "make the rich richer, and the poor get poorer." Moreover, from the aspect of Human Rights, Economic freedom is also often seen as two things that are contradictory or even threatening one another. ${ }^{20}$

Milton Friedman, an economist in the United States, is known as one of his quotes, "The business of business is business. And the social responsibility for business is to increase its profits." By some people, this is often the basis for business and economic freedom to become a threat to human rights itself. Child labor systems (child labor) to the exploitation of developing countries are examples of arguments that assume that economic freedom and human rights are in different dimensions. ${ }^{21}$

Another problem is the implementation of World Trade Organization Law (WTO Law) as the main reference for the implementation of international trade and economy and the WTO Law is very capitalism and liberalism. When international laws and policies, including WTO law, are applied within already-discriminatory domestic societal structures, they can easily exacerbate existing disparate levels of enjoyment of economic and social benefit ${ }^{22}$ as in Indonesia. In such circumstances, States may have human rights law obligations to ensure that discrimination does not occur is stopped. The article begins by exploring and analyzing the relationship between the political economic policies and human rights and their further issues in Indonesia. Furthermore, the article also analyzed some contemporary issues concerning to economic policy as well as its relations to the human rights.

\section{RESEARCH METHODS}

This research is a normative legal research where the author examines secondary data in the form of research reports, journal articles, books, and cases obtained both through print and online media. This study uses an approach to the study of human rights on the issues of national and international economic policies that apply in Indonesia. This research is not a field research and is not an in-depth study, because the author only looks at the facts and that facts obtained through various media and analyzes them based on international and national human rights legal instruments.

Studies in this research include studies of international economic law, international law, and law and human rights. This research also recognized as descriptive legal science in the legal doctrinal approach, as emphasized by Jan M. Smits, that this type of research provides the systematic description of the law in certain field, and at this research focus on international economic law and human rights law which intersect with economic description of law. ${ }^{23}$

\section{RESULT AND DISCUSSION}

\section{International Trades: The Bias of Free Trade and Economic Welfare}

Economics, Business and Trade are one of the important sectors in Indonesia's development. Various economic policies were issued to maintain national economic stability and the sustainability of investment. The various economic policies present are aimed at ensuring economic prosperity and justice in the economy. However, the fact is, in any social or economic policy debate, welfare economics seeks to provide a comparative measure of optimal social utility derived from alternative policy or investment options such that the option with the optimal social utility can be chosen. It is as emphasized by Salomon and Arnott $^{24}$ that much of the human rights critique of economics has actually focused on neoliberal economic policies such as privatization, low tax and public expenditure, and deregulation, as some commentators have correctly identified there is a

2019, Vol. 2 No. 2, pp. 142-158. Retrieved from http://e-jurnal.unisda.ac.id/index.php/mimbar/article/view/1344; Anis Widyawati, Ridwan Arifin, "The Protection of Illegal Immigrants under Indonesian National Law and International Law", Advances in Social Science, Education and Humanities Research, Proceedings of the 1st International Conference on Indonesian Legal Studies (ICILS 2018), 2018, Vol. 192, pp. 305-308. DOI: https://doi.org/10.2991/icils-18.2018.58

20 EFN, "Hak Asasi Manusia dan Kebebasan Ekonomi: Benarkah Beda Dimensi?", Online News, 5 December 2016, retrieved from https://indonesia.fnst.org/content/hak-asasi-manusia-dan-kebebasan-ekonomi-benarkah-beda-dimensi

21 Ibid.

22 Gillian Moon, "Fair in Form, But Discriminatory in Operation--WTO Law's Discriminatory Effects on Human Rights in Developing Countries", Journal of International Economic Law 2011, Vol. 14 No. 3, p. 555.

23 Jan M. Smits, The Mind and Method of the Legal Academic, Edward Elgar, Cheltenham, UK, 2012, p.23.

24 Margot E. Salomon and Colin Arnott, Loc.Cit. 
fundamental failure to translate the requirements of human rights into the principles and assumptions that guide neoclassical/mainstream economics (including neoliberal economics in so far as it is underpinned by the same economic principles and assumptions).

Neoliberalism as well as capitalism in economics sectors has brought a lot of negative impacts in various countries including Indonesia, and even has an impact on multi-sectors including in education, health, and agriculture. In fact, trades and economics-which is currently influenced by liberalism and capitalism-has become one of the important things in terms of growth, which in Salvatore's terminology, trade has become a tool for growth. ${ }^{25}$

However, in terms of etymology, trade is any form of activity selling and buying goods or services in a place, where there is a balance between the demand curve and supply at one point commonly known as the equilibrium point. While international means a world that is wide and global, not partial or one particular region. Thus, international trade can be interpreted, a number of trade/sale transactions between buyers and sellers (which in this case one country with another in the form of exports and imports) on a market, in order to achieve maximum benefits for both parties. Several hundred years ago, the Mercantilist school thought that international trade was a profit-loss transaction or a win-lose deal. According to this flow, exports are something that is profitable (win) while imports are a detrimental thing (lose) so the state must pursue exports and avoid imports. ${ }^{26}$

The concept of international trade has emerged since the $17^{\text {th }}$ and $18^{\text {th }}$ centuries regarding the economic philosophy-Mercantilism, which is according to the theory that the only way for a country to become rich and strong is to do as much export as possible and as little as possible import. ${ }^{27}$ Furthermore, Salvatore explains several theories concerning to international trade.

\section{a. Absolute Excellence Theory}

According to Adam Smith the trade of two countries is based on absolute advantage, namely if a country is more efficient than other countries in producing a commodity, but less efficient than other countries in producing other commodities, then both countries can benefit by their own way. Each specializes and produces commodities that have absolute advantages and exchange for other commodities that have absolute losses. Through this process, resources in both countries can be used in the most efficient way. The output produced will also increase. ${ }^{28}$

\section{b. Comparative Excellence Theory}

According to David Ricardo, even though a country is less efficient than (or has absolute losses) with other countries in producing two commodities, there is still a basis for being able to trade that benefits both parties. The country must specialize in producing and exporting commodities that have smaller absolute losses, and import commodities that have greater absolute losses. ${ }^{29}$

\section{c. Proportion of Production Factor Theory}

According to Ohlin Heckscher there are two important conditions as the basis for the emergence of international trade, namely the availability of factors of production and the intensity of the use of factors of production or the proportion of factors of production. A country will trade with other countries because the country has a comparative advantage, namely excellence in technology and excellence in production factors. ${ }^{30}$

\section{d. Competitive Advantage Theory}

According to Michael E. Porter in the Competitive Advantage of Nation theory, that there is no direct correlation between the two factors of production (high natural resources and cheap human resources) owned by a country to be utilized as a competitiveness in trade. There are four main attributes that determine why certain industries in a country can achieve international success, namely: 1) Conditions of production factors, 2) Demand conditions and domestic quality demands, 3) Existence of supporting industries, 4) Competitive conditions of strategies and corporate structures in country. ${ }^{31}$

25 Salvatore stated that trade as engine of growth, see Dominick Salvatore, Ekonomi Internasional, Jakarta, Erlangga, 2004, pp. 47-48.

26 Ibid., p. 49.

27 Ibid

28 Dominick Salvatore, Ekonomi Internasional, Jakarta, Erlangga, 2004, pp. 58-60; Tulus Tambunan, Perekonomian Indonesia: Teori Dan Temuan Empiris, Jakarta, Salemba Empat, 2001, pp. 34-39; Heri Setiawan, and Sari Lestari, Perdagangan Internasional, Yogyakarta, Pustaka Nusantara, 2011, pp. 56-59.

29 Ibid.

30 Ibid.

31 Ibid. 
Setiawan and Lestari ${ }^{32}$ also describe that there are several factors that become the cause of the emergence of international trades, such as, information and transportation revolution, interdependent needs, economic liberalization, comparative advantages principle, and also foreign exchange needs. Information and transportation, as Setiawan and Lestari emphasized, that marked by the development of the information age of technology, the use of computer-based systems and advancements in the field of information, the use of satellites and the digitalization of data processing, the development of communication equipment and much more. Then, related to interdependent needs stated that each country has advantages and advantages in each aspect, can be analyzed from natural, human, and technological resources. All of that will have an impact on the dependence between countries with each other. Further, in the economic liberalization, it is said that freedom in conducting transactions and conducting work together has implications that each country will look for opportunities by interacting through trade between countries.

Moreover, Setiawan and Lestari, explained that in the principle of comparative advantage, the uniqueness of a country is reflected in what the country has that is not owned by other countries. This will make the country have an advantage that can be relied upon as a source of income for the country. About foreign exchange needs, Setiawan and Lestari underlined that international trade is also influenced by factors in the need for foreign exchange of a country. In fulfilling all its needs, every country must have foreign exchange reserves used in carrying out development and one of the sources of foreign exchange is income from international trade. ${ }^{33}$

Various trade agreements in the context of the international economy, are legally binding within the framework of international treaty law. The trade carried out, leads to a free trade practice, in which Indonesia has also implemented this practice, for example in several agreements such as the ASEAN Free Trade Area (AFTA), the Indonesia-Australia Comprehensive Economic Partnership Agreement (CEPA), and the China ASEAN Free Trade Area (CAFTA), has an impact on socio-economic changes in society. ${ }^{34}$ The various free trade agreements that have been made and agreed upon, basically also emphasize the importance of productivity accompanied by the principle of equality, justice, protection of human rights and the environment, but again when talking about reality, it might be worth reviewing concerning the truth set forth those principles. James Petras ${ }^{35}$ has quite critically said that the discourses that we have always considered normal should be critically scrutinized. This mode of free trade will not only be a mechanism for mastering developed countries towards developing countries. Neoliberalism or referred to as an economic notion that prioritizes the capitalist system of free trade, for the inevitability of economic market integration is nothing more than myths and claims that are always built for the benefit of imperialist relations.

In line with what was described earlier, it is said that free trade is a form of market fundalism (funding concept) that might destroy the implementation of human rights. The free market has a very critical relationship with human rights, but between free markets and human rights does not have too much contradiction. However, free markets can destroy human rights values and frameworks or assist in implementing fulfillment of human rights in Indonesia. In the next section, this paper will analyze at how relations and even human rights issues arise from the practice of Indonesian economic and trade policies. As previously mentioned, even free trade and other economic policies indicate the practice of economic policies of liberalism and capitalism, with some experts arguing that such practices can be debilitating and that they exclude basic human rights values.

\section{The Indonesian Political Economy and Human Rights (Various Contemporary and Controversial Economic Policies)}

Economic policy is the way taken or actions taken by the government with the aim of regulating the national economic life in order to achieve certain goals. ${ }^{36}$ International economic policies in the broad sense include all economic activities of a country's government that directly or indirectly affect the composition, direction and activities of export and import of goods and services carried out by the government. Therefore, even if a policy is aimed at overcoming domestic problems, if it directly or indirectly influences exports and imports it can be included in international economic policies.

32 Heri Setiawan, and Sari Lestari, Perdagangan Internasional, Yogyakarta, Pustaka Nusantara, 2011, p. 61

33 Ibid. pp. 62-63

34 Hendra Manurung, Improving Free Trade Agreement (FTA) Between Indonesia-European Union (EU) Through Comprehensive Economic Partnership Agreement (CEPA)", Asia Pacific Studies, Volume 2 No. 1, January-June 2018, pp. 23-44

35 James Petras said that overseas economic exploitation has transferred income to 'buy-off' the domestic working and middle classes, in the course of consolidating imperial hegemony, see James Petras, "US Empire: Global Imperialism and Internal Colonialism", Online Article, 20 March 2018, retrieved from https://petras.lahaine.org/us-empire-globalimperialism-and-internal/

36 T Gilarso, Pengantar Ilmu Ekonomi Makro, Penerbit Kanisius, Yogyakarta, 2004, p. 225 
International economic policy in the narrow sense only covers policies that directly affect exports and imports. International policy in this narrow sense is related to the export of goods and services, therefore the scope is very broad considering the number of goods or services exported or imported, ranging from consumer goods, production to labor. ${ }^{37}$

On the side of economic policy, human rights are inherent in the form of implementation, where human rights in the economic sector are defined as rights to economy, equality and non-discrimination. Further, emphasized that human rights are rights owned by every human being who has been born since and this right cannot be replaced or contested by anyone. Indeed, every citizen upholds human rights without differentiating between one citizen and another. In the economic field, economic rights (property rights) are certainly manifested in the form of the right to own, buy, sell and use something. In the economy, equality in its legal economic rights must be protected by the state. Of course the mechanism, the state must create a supportive atmosphere through legislation. ${ }^{38}$

Therefore, the state through its government apparatus must not discriminate, favoritism, privilege to certain people and groups, exclusivity, and others. Therefore, the state through its government apparatus must not discriminate, favoritism, privilege to certain people and groups, exclusivity, and others. So, economic justice is the first pillar that must be fought for. ${ }^{39}$

Many cases of economic injustice or inequality are visible in front of us. Economic injustice, in fact many are produced by the state through their apparatus. The Jakarta Bay reclamation case, for example, which is unfeasible in academic studies, is forced by the state in consideration of economic benefits. The advantage for big business people with bright lights has discriminated against the environment of the biota and the livelihood of the people, especially the fate of fishermen. ${ }^{40}$

One example of a case related to economic rights in Indonesia, namely, the case of delinquent payment of salaries of employees of the Riau governor's cleaning service by the outsourcing company CV Ratu. The chronology of this case is where hundreds of cleaning services at the Riau Governor's Office and its surroundings have not received salaries so far. The origin of the problem of the workers and the company CV Ratu is a four-month paycheck made by the company, workers are trying to ask for confirmation from the company that hired them. The reason for the company is that the company has not received payment by the Riau Provincial Government, but the company continues to make an effort to immediately pay the entire arrears of the workers' salaries of Rp.1,750,000 per month. But on the other hand the Riau Provincial Government asserted that the company CV Ratu to immediately pay off the salaries of workers, because given that there is no reason for the company to delay its obligations. Until now the workers agreed to be forced to report this problem to the Riau Regional Police. ${ }^{41}$

That case highlighted that the problems between workers and CV. Ratu who is an outsourcing company that employs them is related to salary payments arrears for four months. This is contrary to the rules contained in Law Number 13 of 2003 concerning Labor (or Labor Act). Previously, we can see the definition of workers in Article 1 point 3 of the Labor Act, namely: "Workers/labors are everyone who works by receiving wages or other forms of rewards." And the relation with wages is stated in the provisions of Article 88 paragraph (1): "Every worker/labor has the right to obtain income that fulfills a decent living for humanity." ${ }^{2}$ Thus, workers and wages are two things that are interrelated with each other, so that wages are rights that must be fought for while carrying out their duties as workers.

Meanwhile, in another case, eLSAM revealed that government policies in the field of economic development did not favor the poor. The brief objectives of systematic economic recovery have weakened the power of the implementation of justice measures and the power of the people's struggle. The Indonesian economy, for its recovery, has chosen the path of economic violence. Short economic goals have been fought through the prac37 Nia Julianti, "Kebijakan Ekonomi dan Perdagangan Internasional”, Online Paper STIE Dr Khiez Muttaqien, https:// www.academia.edu/21971951/Makalah_kebijakan_ekonomi_dan_perdagangan_Internasional

38 Idjehar emphasized that economic rights (property rights) are the right to own, buy and economic rights are rights related to economic life. Or the right given to be able to own, buy and sell, and utilize something. See Muhammad Budairi Idjehar, HAM versus Kapitalisme, Yogyakarta, INSIST Press, 2003, pp. 45-46. Another perspectives, see also Muhammad Ali Masnun, "Legal Protection of the Right to Indication of Origin in Indonesia", Journal of Private and Commercial Law, 2018, Vol. 2 No. 2, pp. 113-124, Retrieved from https://journal.unnes.ac.id/nju/index.php/jpcl/ article/view/16875

39 Bukhaer Pakkanna, "Hak Asasi Ekonomi dan Inteleransi”, Online Article, 10 December 2017, retrieved from https:// geotimes.co.id/kolom/ekonomi/hak-asasi-ekonomi-dan-intoleransi/

40 Ibid.

41 LBH Pekanbaru, "Kasus Penunggakan Pembayaran Gaji Karyawan Cleaning Service Kantor Gubernur Riau oleh Perusahaan Outsourcing CV. Ratu", Online Article, retrieved from https://www.lbhpekanbaru.or.id/kasus-penunggakanpembayaran-gaji-karyawan-cleaning-service-kantor-gubernur-riau-oleh-perusahaan-outsourching-cv-ratu/

42 Law Number 13 of 2003 concerning Labor 
tice of impoverishment, extortion and violence. Furthermore, the state budget shows a smaller general welfare budget from the military budget. This confirms the assumption that Indonesia's economic recovery has been achieved by increasing the ability of the security apparatus rather than increasing the welfare of its citizens. ${ }^{43}$

\section{Economic Rights in International Conventions and International Economic Law Regime: The Relations with Human Rights}

Article 1 paragraph (1) of Law No.39 of 1999 concerning Human Rights states that "Human Rights are a set of rights that are inherent in the nature and existence of human beings as God Almighty and is a gift that must be respected, upheld high and protected by the state, law, government, and everyone for the sake of respect and protection of human dignity." ${ }^{44}$ Hendarmin Ranadireksa said that human rights are essentially a set of rules or rules to protect citizens from the possibility of oppression, suppression and or limitation of space citizens by the state, which means that there are certain restrictions imposed on the state so that the most essential rights of citizens are protected from the arbitrariness of the power exercised by the government. ${ }^{45}$

According to Mahfud $\mathrm{MD}^{46}$ human rights are interpreted as rights inherent in human dignity as creatures of God, and these rights are brought by humans from birth to the face of the earth so that these rights are natural (natural), not human or state gifts. Thus it can be concluded that human rights are the basic rights inherent in each individual from birth to the face of the earth and not a gift of humans or authorities that must be protected and cannot be reduced without any reason.

In 1948, precisely on December 10, 1948 a general agreement was formed from the international community to guarantee and protect human rights. The general agreement is the Universal Declaration of Human Rights (UDHR) which contains articles relating to Human Rights and in 1966 an international legal instrument concerning Human Rights was agreed, namely: International Covenant on Civil and Political Rights (ICCPR), the International Covenant on Economic, Social and Cultural Rights (ICESCR), and Additional Protocols Covenant on Civil and Political Rights (the Optional Protocol on Civil and Political Rights).

Economic and social rights are very strategic human rights to fight for and fulfill, in line with this view expressed by Robertson that Civil and Political Right may be fundamental, be they cannot be enjoyed on an empty stomach, talk to holocaust survivors, and they will tell you that racial discrimination, slavery and loss of liberty) were not the immediate concern....but rather an aching and all enveloping hunger. Of course, starvation was inflicted as a consequence of an inhuman racist policy, but it endangered their right to life more directly than depriving them of civil liberties. ${ }^{47}$

In the articles of the two conventions (ICCPR and ICESCR) participated in the 1948 UDHR. Both set up a monitoring system which according to many scholars was rather weak. This shows the UDHR's important role in human rights in general, and human rights to the economy in particular. In connection with international economic law, the following description emphasizes the convention on economic, social and cultural rights (ICESCR).

\section{a. Economic Rights (Rights to Economy)}

This right to economy is contained in the Covenant on Rights Economics, Social and Culture. This right, according to Henkin ${ }^{48}$, is known as the second general (second generation) right of human rights. From the articles of the ICESCR express human rights to the economy, namely:

1) the right to work;

2) the right to a decent salary with his job;

3) the right to join a trade/labor union;

4) the right to rest (leisure);

5) the right to get a decent standard of living (adequate

43 eLSAM, "Laporan Hak Asasi Manusia 2003: Melemahnya Daya Penegakan Hak Asasi Manusia : Hutang, Kemiskinan dan Kekerasan", Research Report, eLSAM, retrieved from http://elsam.or.id/2003/12/melemahnya-daya-penegakan-hak-asasi-manusia-hutang-kemiskinan-dan-kekerasan/, see also Ridwan Arifin, "Revealing the Other Side of Human Rights Issue: How We Look to the Existed Various Problems", Journal of Indonesian Legal Studies (JILS), 2017, Vol. 2 No. 1, pp. 79-82, Retrieved from https://journal.unnes.ac.id/sju/index.php/jils/article/view/16642

44 Law No.39 of 1999 concerning Human Rights (Indonesian Human Rights Act)

45 Erlina B, "Pengaruh Globalisasi Terhadap Perkembangan Hak Asasi Manusia Bidang Ekonomi, Sosial, Budaya (HESB) di Indonesia", Pranata Hukum, 2011, Vol. 6 No. 2, pp. 103-116.

46 See Moh. Mahfud MD, Dasar \& Struktur Ketatanegaraan Indonesia, Rineka Cipta, Jakarta, 2001, pp. 23-25;

47 Goeffrey Robertson, Crimes Against Humanity: The Struggle for Global Justice, London, Penguin Books, 2002 , pp. 154-155; see also Steven Freeland, "Geoffrey Robertson Crimes Against Humanity: The Struggle For Global Justice (2nd Edition) 2002 Penguin Books, London”, Australian Journal of Human Rights, 2003, Vol. 9 No. 2,

48 Louis Henkin, The Age of Rights, New York, Columbia University Press, 1990, pp. 13-15. 
6) standard of living) which includes food, clothing, housing, health, and social services;

7) the right to education, including free basic education, and

8) the right to participate in cultural life in the community.

b. Right to Work

The right to work is contained in Article 6 of the ICESCR and this right is an essential part of the human condition. Affirmation of this right according to Jacquart, is rather difficult to achieve. There are two reasons that support his opinion. First, although the ICESCR affirms the existence of rights to work, the ICESCR also recognizes the existence of other rights, namely the right to social security. Secondly, the implementation of this right is very dependent on the ability of the government to provide employment to its citizens. Therefore, Jacquart believes that the right to work is more appropriately referred to as the right of access to work. ${ }^{49}$

\section{c. Right to Salary and Eligible Conditions}

This right is contained in article 7 of the ICESCR. This right is closely related to the right to work. This right is also an absolute right. The International Labor Organization (ILO) has issued various legal instruments to strengthen these rights. These instruments included Convention No. 131 and Recommendation No. 135 of 1970 which regulated the stipulation of minimum wages. ${ }^{50}$

\section{d. The Right to Establish and Join a Trade Union}

Article 8 of the ICESCR contains the right to form and join with trade unions. The provisions of this article constitute mandatory rights. In a sense, the state must guarantee his citizens or work to join in the trade unions he likes. Included in this right is the right to strike.

This right has been strengthened by various resolutions and international agreements formulated in the ILO. An example is issued an instrument entitled Freedom of Association and Protection of the Right to Organize, Convention No. 87 dated July 9, 1948.

e. Right to Rest

This right is contained in article 7 (d). This article confirms, is the right of everyone to enjoy a break from their work, including enjoying a holiday and vacation (by still getting a salary payment).

\section{f. The Right to Obtain Adequate Standard of Living (includes Food, Clothing, Housing, Health and Social Ser-} vices)

This right is listed in Articles 10, 11 and 12 of ICESCR. This right especially Article 11 is the most widespread and general of the articles in the Covenant. The rights to obtain a decent standard of living are also included in the right to protection of the family (article 10). Article 10 paragraph (3) even requires the state to punish anyone who exploits small children, especially those who make children as workers.

In relation to this right, there are also important rights namely the right to food, clothing, housing, health, and social services. The provisions of the right to food are affirmed in article 11 paragraph 2 which states that the fundamental right of everyone to be free from hunger.

According to Jacquart, the provisions of this article indicate the state either individually or together with other countries to take steps or ways needed to improve food production, conservation and distribution. Also included in this case is food distribution that is fair to the world according to their needs. ${ }^{51}$

It needs to be explained here that the right to a decent standard of living is a prerequisite for the realization of the rights of other lives. According to Jacquart, ${ }^{52}$ the absence of this right would result in economic (and social) rights not being met (fulfilled). This opinion is appropriate, because how can other economic rights be implemented if the basic rights, namely the right to an adequate standard of living are not fulfilled. The ILO has issued various instruments that require countries (members) to respect this right. These instruments include:

1) The Universal Declaration on the Eradication of Hunger and Malnutrition ${ }^{53}$; and

2) Resolution 41/190 dated 8 December 1986 which affirmed the right to food as fundamental human rights that must be guaranteed for all people. This resolution also states that the provision of these foods should not be used as a suppressing instrument or instrument at the national or international level.

Regarding the significance or significance of this right, Matthew Craven stated that there is no doubt that the right to an adequate standard of living, including the rights to food, housing and clothing is of paramount 49 M. Jacquart, "Economic, Social and Cultural Rights", in M. Bedjaoui (ed.), International Law: Achievements and Prospects, The Netherlands, United Nations Educational, Scientific, and Cultural Organization, 1991, pp. $1083-1104$. 50 ILO Convention No. 131, Recommendation No. 135 of 1970

51 M. Jacquart, Op.Cit.

52 Ibid.

53 See OHCHR, "Universal Declaration on the Eradication of Hunger and Malnutrition", retrieved from https://www. ohchr.org/en/professionalinterest/pages/eradicationofhungerandmalnutrition.aspx 
importance not least because at minimum levels it represents a question of survival. ${ }^{54}$

\section{g. Right to Education, Including Free Basic Education}

This right is regulated in Articles 13 and 14 of the ICESCR. This right really is the implementation of Article 26 of the Universal Declaration of Human Rights. Paragraph 2 of Article 26 confirms the purpose of these rights to education, namely:

1) develop human personality comprehensively;

2) increasing respect for human rights and human rights and fundamental freedoms;

3) increase tolerance;

4) increase understanding and brotherhood among all country, race, religious group; and

5) advance $U N$ activities and maintain peace.

The right to education is stipulated in Articles 13 and 14 ICESCR. In particular Article 14, based on this article the participating countries are required to make an action plan to fully implement the principle of free and compulsory basic education.

\section{h. The Right to Participate in Cultural Life in the Community}

This right is contained in Article 15 of the ICESCR. According to Jacquart, this right will only be enjoyed if the appropriate standard rights beforehand can or have been fulfilled. This right includes the right to participate in cultural life, the right to benefit from scientific progress, the right to protection from artistic objects, writing or other material (which is harmful) originating from science, the right to freedom of research, communication and information..$^{55}$

The values and principles of economic rights are articulated in the UDHR and summarized all the values underlying the modern international human rights system: universality, dignity, independence (or freedom), justice, equality (or fairness, also including distributive justice), accountability (government), participation, empowerment, and a sense of brotherhood (or solidarity) between people. ${ }^{56}$

Rules in trade, also including rules in the WTO, are based on the same values as human rights: freedom and individual responsibility, non-discrimination, law enforcement, and welfare through peaceful cooperation between individuals. Ernst-Ulrich Petersmann also stated that the WTO regime promotes freedom (in eliminating trade restrictions), discrimination (in the form of Most Favored Nation / MFN and National Treatment / NT), rule of law (in relation to WTO member countries to be transparent with obligations and implementation according to a system based on international trade), and economic efficiency in improving welfare. ${ }^{57}$

\section{CONCLUSION}

Economic rights are one of the fundamental rights listed in various international human rights conventions, whether ICCPR, ICESR, or UDHR itself. The economic and trade sectors have a close relationship with the fulfillment of human rights. In many cases in Indonesia, both national and international economic policies have an impact on the fulfillment of economic rights which are also included in human rights. The International Economic Law Regime also recognizes in detail about human rights which intersect directly with human rights, one of which is various rules of international trade and WTO Law. Political measures of economic policy, both in the form of austerity, subsidy reduction, tax and salary policies, or investment development, have a direct impact on the fulfillment of basic human rights.

\section{BIBLIOGRAPHY}

Arifin, Ridwan, Rasdi, Riska Alkadri. (2018). “Tinjauan atas Permasalahan Penegakan Hukum dan Pemenuhan Hak dalam Konteks Universalisme dan Relativisme Hak Asasi Manusia di Indonesia”, Jurnal Ilmiah Hukum LEGALITY, Vol. 26 No.1, pp. 17-39, DOI: https://doi.org/10.22219/jihl.v26i1.6612.g5770

Arifin, Ridwan. (2017). "Revealing the Other Side of Human Rights Issue: How We Look to the Existed Various Problems", Journal of

54 Matthew Craven, The International Covenant on Economic, Social and Cultural Rights, A Perspective on Its Development: Oxford Monographs in International Law, Oxford, Clarendon Press, 1995, pp. 125-127; also see Rein Müllerson, "The International Covenant on Economic, Social and Cultural Rights. A Perspective on its Development . By Matthew Craven. Oxford: Clarendon Press, 1995. 413 pp. £50”, British Yearbook of International Law, Volume 68, Issue 1, 1 January 1998, pp. 274-276, DOI: https://doi.org/10.1093/bybil/68.1.274

55 M. Jacquart, Op.Cit.

56 Johannes Morsink, "The Philosophy of the Universal Declaration", Human Rights Quarterly, 1982, Vol. 4 No. 2 , p.391

57 Ernst-Ulrich Petersmann, “Time for a United Nations 'Global Compact' for Integrating Human Rights into the Law of Worldwide Institutions: Lessons from European Integration”, European Journal of International Law, 2002 , Vol. 13 No. 3, pp. 621-636. 
Indonesian Legal Studies (JILS), Vol. 2 No. 1, pp. 79-82, Retrieved from https://journal.unnes.ac.id/sju/index.php/jils/article/ view/16642

Angga \& Arifin, Ridwan. (2018). “Penerapan Bantuan Hukum Bagi Masyarakat Kurang Mampu”, DIVERSI Jurnal Hukum, Vol. 4 No. 2 , pp. 218-236, DOI: https://doi.org/10.32503/diversi.v4i2.374

Anonym. (2018). "Economy of Indonesia is Facing Several Big Challenges", Online Article, 6 July 2018, retrieved from https://www. indonesia-investments.com/news/news-columns/economy-of-indonesia-is-facing-several-big-challenges/item 8882 ?

Armenia, Restry. (2016). "Kebijakan Migrasi Pekerja Dinilai Picu Pelanggaran HAM Buruh", Online News, 8 March 2016, retrieved from https://www.cnnindonesia.com/nasional/20160307142904-26-115831/kebijakan-migrasi-pekerja-dinilai-picu-pelanggaranham-buruh

Bisariyadi. (2017). “Menyibak Hak Konstitusional yang Tersembunyi”, Jurnal Hukum Ius Quia Iustum, Vol. 24 Issue 4, October, pp. 515518, DOI: 10.20885/iustum.vol24.iss4.art1

Branco, Manuel Couret. (2009). "Economics Againts Human Rights (The Conflicting Languages of Economics and Human Rights)", Capitalism Nature Socialism, Vol. 20 No. 1, pp. 88-102., retrieved from https://www.ces.uc.pt/ces/eventos/pdfs/manuel branco. pdf

Craven, Matthew. (1995). The International Covenant on Economic, Social and Cultural Rights, A Perspective on Its Development: Oxford Monographs in International Law. Oxford: Clarendon Press.

Cottier, Thomas. (2019). "Challenges Ahead in International Economic Law”, Journal of International Economic Law, Vol. 12 No. 1, pp. $1-30$.

EFN. (2016).“Hak Asasi Manusia dan Kebebasan Ekonomi: Benarkah Beda Dimensi?”, Online News, 5 December 2016, retrieved from https://indonesia.fnst.org/content/hak-asasi-manusia-dan-kebebasan-ekonomi-benarkah-beda-dimensi

eLSAM. (2003). "Laporan Hak Asasi Manusia 2003: Melemahnya Daya Penegakan Hak Asasi Manusia: Hutang, Kemiskinan dan Kekerasan", Research Report, eLSAM, retrieved from http://elsam.or.id/2003/12/melemahnya-daya-penegakan-hak-asasi-manusia-hutang-kemiskinan-dan-kekerasan/

Engström, Viljam. (2016). “The Political Economy of Austerity and Human Rights Law”, Institute for Human Rights Working Paper, No. 1/2016, Abo Academy University, pp. 1-16.

Erlina B. (2011). "Pengaruh Globalisasi Terhadap Perkembangan Hak Asasi Manusia Bidang Ekonomi, Sosial, Budaya (HESB) di Indonesia", Pranata Hukum, Vol. 6 No. 2, pp. 103-116.

Fuad, Fokky. (2007). "Hukum, Demokrasi, dan Pembangunan Ekonomi”, Lex Jurnalica, Vol.5 No. 1, December, pp. 1-10.

Freeland, Steven. (2003). "Geoffrey Robertson Crimes Against Humanity: The Struggle For Global Justice (2nd Edition) 2002 Penguin Books, London”, Australian Journal of Human Rights, Vol. 9 No. 2, pp. 37-58

Garcia, Frank J. (2017). “ Globalization, Inequality \& International Economic Law”, Religions, Vol. 8 No. 78, pp. 1-12, DOI: 10.3390/ rel8050078

Gayatri, Aprilia et.al. (2008). "Hak Asasi Manusia dan Hukum Ekonomi Internasional, Kovenan Hak-Hak Ekonomi, Sosial dan Budaya/ ICESCR 1966”, Paper on International Economic Law, Bandung, Faculty of Law Universitas Padjadjaran.

Gilarso, T. (2004). Pengantar Ilmu Ekonomi Makro, Yogyakarta: Penerbit Kanisius.

Henkin, Louis. (1990). The Age of Rights. New York: Columbia University Press.

Idjehar, Muhammad Budairi. (2003). HAM versus Kapitalisme. Yogyakarta: INSIST Press.

ILO Convention No. 131, Recommendation No. 135 of 1970

Jacquart, M. (1991). "Economic, Social and Cultural Rights", in M. Bedjaoui (ed.), International Law: Achievements and Prospects, The Netherlands, United Nations Educational, Scientific, and Cultural Organization, pp. 1083-1104.

Julianti, Nia. (2016). "Kebijakan Ekonomi dan Perdagangan Internasional", Online Paper STIE Dr Khiez Muttaqien, https://www.academia.edu/21971951/Makalah kebijakan ekonomi dan perdagangan Internasional

Kinley, David. (2009). Civilising Globalisation: Human Rights and the Global Economy, Cambridge, Cambridge University Press, pp. 38-40.

Law Number 13 of 2003 concerning Labor (Indonesian Labor Act)

LBH Pekanbaru, "Kasus Penunggakan Pembayaran Gaji Karyawan Cleaning Service Kantor Gubernur Riau oleh Perusahaan Outsourcing CV. Ratu”, Online Article, retrieved from https://www.lbhpekanbaru.or.id/kasus-penunggakan-pembayaran-gaji-karyawancleaning-service-kantor-gubernur-riau-oleh-perusahaan-outsourching-cv-ratu/

Mahfud MD, Moh. (2001). Dasar \& Struktur Ketatanegaraan Indonesia. Jakarta: Rineka Cipta.

Manurung, Hendra. (2018). Improving Free Trade Agreement (FTA) Between Indonesia-European Union (EU) Through Comprehensive Economic Partnership Agreement (CEPA)", Asia Pacific Studies, Volume 2 No. 1, January-June 2018, pp. 23-44.

Masnun, Muhammad Ali. (2018). "Legal Protection of the Right to Indication of Origin in Indonesia", Journal of Private and Commercial Law, Vol. 2 No. 2, pp. 113-124, Retrieved from https://journal.unnes.ac.id/nju/index.php/jpcl/article/view/16875

Moon, Gillian. (2011) "Fair in Form, But Discriminatory in Operation--WTO Law's Discriminatory Effects on Human Rights in Developing Countries", Journal of International Economic Law, Vol. 14 No. 3, pp. 553-592. DOI: 10.1093/jiel/jgr023

Müllerson, Rein. (1998). "The International Covenant on Economic, Social and Cultural Rights. A Perspective on its Development . By Matthew Craven. Oxford: Clarendon Press, 1995. 413 pp. £50”, British Yearbook of International Law, Volume 68, Issue 1, 1 January 1998, pp. 274-276, DOI: https://doi.org/10.1093/bybil/68.1.274

Nisar Mohammad bin Ahmad. (2011). “The Economic Globalisation and its Threat to Human Rights”, International Journal of Business and Social Science, Vol. 2 No. 19, October, pp. 273-280.

OHCHR. (2008). "Universal Declaration of Human Rights", United Nations Human Rights Office of the High Commissioner, retrieved from https://www.ohchr.org/en/udhr/pages/Language.aspx?LangID=inz, also United Nations, "Universal Declaration of Human Rights", retrieved from http://www.un.org/en/universal-declaration-human-rights/

OHCHR, "Universal Declaration on the Eradication of Hunger and Malnutrition", retrieved from https://www.ohchr.org/en/professionalinterest/pages/eradicationofhungerandmalnutrition.aspx

Pakkanna, Bukhaer. (2017). "Hak Asasi Ekonomi dan Intoleransi”, Online Article, 10 December 2017, retrieved from https://geotimes. co.id/kolom/ekonomi/hak-asasi-ekonomi-dan-intoleransi/ 
Petras, James, (2018). “US Empire: Global Imperialism and Internal Colonialism”, Online Article, 20 March 2018, retrieved from https:// petras.lahaine.org/us-empire-global-imperialism-and-internal/

Petersmann, Ernst-Ulrich. (2012). "Human Rights and International Economic Law: Common Constitutional Challenges and Changing Structures”, EUI Working Papers, SSRN Electronic Journal, No. LAW 2012/07, pp. 11-12 DOI: 10.2139/ssrn.2069895

Petersmann, Ernst-Ulrich. (2002). “Time for a United Nations 'Global Compact' for Integrating Human Rights into the Law of Worldwide Institutions: Lessons from European Integration”, European Journal of International Law, Vol. 13 No. 3, pp. 621-636.

Putri, Kania Dewi Andhika \& Arifin, Ridwan. (2019). “Tinjauan Teoritis Keadilan dan Kepastian dalam Hukum di Indonesia (The Theoretical Review of Justice and Legal Certainty in Indonesia)", MIMBAR YUSTISIA Jurnal Hukum dan Hak Asasi Manusia, Vol. 2 No. 2, pp. 142-158. Retrieved from http://e-jurnal.unisda.ac.id/index.php/mimbar/article/view/1344.

Reid, Lindsey. (2019). "The Generations of Human Rights", Online Article, Institute for Human Rights The University of Alabama at Birmingham, January 14, retrieved from https://cas.uab.edu/humanrights/2019/01/14/the-generations-of-human-rights/

Robertson, Goeffrey. (2002). Crimes Against Humanity: The Struggle for Global Justice. London: Penguin Books.

Salomon, Margot E. and Colin Arnott. (2014). "Better Development Decision-making: Applying International Human Rights Law to Neoclassical Economics”, Nordic Journal of Human Rights, Vol. 32, No. 1, pp. 44-74.

Salvatore, Dominick. (2004). Ekonomi Internasional. Jakarta: Erlangga.

Setiawan, Heri and Sari Lestari. (2011). Perdagangan Internasional. Yogyakarta: Pustaka Nusantara.

Smits, Jan M. (2012). The Mind and Method of the Legal Academi. Cheltenham, UK: Edward Elgar.

Sunardi, Lili. (2015).“Paket Kebijakan Ekonomi Berpotensi Picu Pelanggaran HAM”, Online News, 11 December 2015, retrieved from https://finansial.bisnis.com/read/20151211/9/500630/paket-kebijakan-ekonomi-berpotensi-picu-pelanggaran-ham

Suntoro, Agus. (2018). "Perlunya Pendekatan HAM dalam Kebijakan Pembangunan Infrastruktur”, Online Article, 15 January 2018, https://nasional.kompas.com/read/2018/01/15/21090441/perlunya-pendekatan-ham-dalam-kebijakan-pembangunan-infrastruktur.

Tambunan, Tulus. (2001). Perekonomian Indonesia: Teori Dan Temuan Empiris. Jakarta:Salemba Empat.

Widyawati, Anis \& Arifin, Ridwan. (2018). "The Protection of Illegal Immigrants under Indonesian National Law and International Law", Advances in Social Science, Education and Humanities Research, Proceedings of the 1st International Conference on Indonesian Legal Studies (ICILS 2018), Vol. 192, pp. 305-308. DOI: https://doi.org/10.2991/icils-18.2018.58

YLBHI, "Hak Ekonomi, Sosial dan Budaya di Negeri yang Kaya: Potret Pelanggaran Hak-hak Ekosob di Indonesia (Januari 2002 - Februari 2003)", Project Report YLBHI, No. 3, March, pp. 1-15, retrieved from http://www.ylbhi.or.id/wp-content/uploads/2013/05/20030000_laporan_no.3_ekosob.pdf 